\title{
Photographic Measurements of the Great Aurora of January 25-26, 1938
}

\section{By Prof. Carl Störmer, Institute of Theoretical Astrophysics, Blindern, Oslo}

$\mathrm{T}^{\mathrm{H}}$ HE great aurora of January 25-26 last was observed and photographed from my nine photographic aurora-stations in southern Norway. From $18^{\mathrm{h}} 16^{\mathrm{m}}$ until $6^{\mathrm{h}} 7^{\mathrm{m}}$ G.M.T., about 1,390 photographs were taken, of which about 710 were successful. Among these, there are 95 sets taken simultaneously from two stations, 48 from three and 14 from four, to determine height and position. Furthermore, about twenty spectra were secured. Besides this, I received about 180 letters with observations from different parts of Norway and about 20 from abroad. The working up of this extensive material will take a long time, but some preliminary results already obtained may be of interest.

My assistant, O. Hassel, who works without telephonic connexion with the other stations, began to take pictures as early as at $18^{\mathrm{h}} 16^{\mathrm{m}}$ G.M.T. A fine series of about sixty pictures had already been taken when the other stations began their work at $19^{\mathrm{h}} 40^{\mathrm{m}}$ G.M.T. Clouds at the eastern stations prevented good simultaneous pictures being obtained before $20^{\mathrm{h}} 11^{\mathrm{m}}$, but from that moment until dawn photographs were taken in rapid succession as fast as possible from all stations connected by telephone. The stations were combined as two sets. Each set, with the main station in Oslo, had up to three secondary stations, and the two sets worked independently of each other. The work was directed from the main stations in Oslo.

Twenty-one sets of simultaneous pictures have so far been measured and calculated. Some of the results are here brought together. Fig. I represents the aurora towards the south photographed from the Tömte station at 21.40.09 G.M.T. Simultaneous pictures were taken from Oslo and Oscarsborg. The arc near the southern horizon was green and persisted for a long time as the southern boundary of the aurora. Above it are seen rays which were of red colour. For a long time the northern half of the sky was quite free from any aurora. With the bass-line Oscarsborg-
Tömte, $73.7 \mathrm{~km}$., the following heights were found : Lower border of the green arc, about $95 \mathrm{~km}$. Base points of rays, from 150 to $200 \mathrm{~km}$. : summits, from 500 to $600 \mathrm{~km}$. The whole aurora was lying in the earth's shadow. The geographical situation of the rays measured is seen on the accompanying map (Fig. 2) over Denmark.

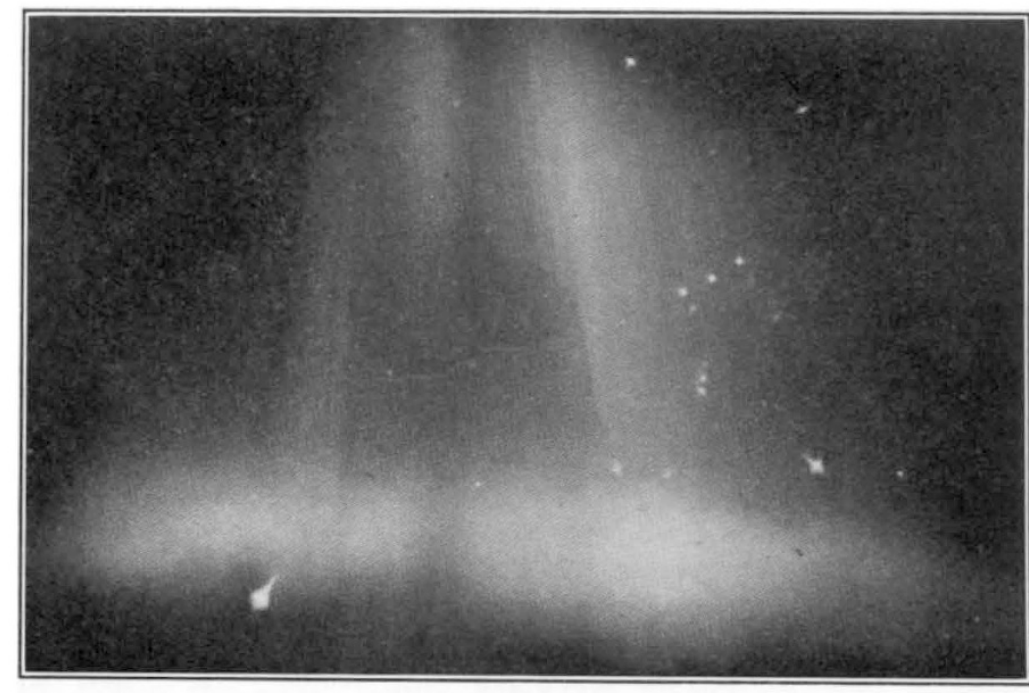

Fig. 1. HOTOGRAPHED FROM TÖMTE, NORTh OF OSLO, AT 21.40.09 G.M.T.

The green arc was lying under the base points of the rays. The further extension of the arc eastwards and westwards could be found from single pictures taken a little before, or after, the set mentioned, the height being supposed to be $95 \mathrm{~km}$. The arc was sometimes single, sometimes double, and stretched from Ösel over Denmark to the northern part of Ireland, as seen on Fig. 2 .

At the same time, two other rays were photographed simultaneously from Askim and Lillehammer. With this base-line, of $173 \mathrm{~km}$., the base points of the rays were found to be at about $106 \mathrm{~km}$. and $108 \mathrm{~km}$., and the summits about $500 \mathrm{~km}$. and $540 \mathrm{~km}$.

All these rays were lying in the earth's shadow, and their great length, up to $400 \mathrm{~km}$. and more, is quite astonishing; it seems to indicate that the high atmosphere is lifted up by the action of the big aurora, like the lifting up by the action of the sunlight in other cases. 
At $21^{\mathrm{h}} 41^{\mathrm{m}}$ G.M.T., the ray-summits had neared the magnetic zenith in Oslo. With the base OsloLillehammer, $133 \mathrm{~km}$., the summits were again measured and gave heights up to $500 \mathrm{~km}$.

A fine corona next developed. The point of radiation found from the Oslo picture at 21.41.40 G.M.T. could be measured with a pre. cision of $\pm 0 \cdot 2^{\circ}$ in altitude and $\pm 0 \cdot 6^{\circ}$ in azimuth, to altitude $70 \cdot 0^{\circ}$, azimuth $6 \cdot 4^{\circ}$ east of south. At 21.45.34 the base points of the rays of the corona in the east were measured with the base-line Oscarsborg-Tömte, and found to be 95-105 km. (parallax, $15-20^{\circ}$ ).

During the later maximum, near midnight G.M.T., new determinations of high rays were made and heights even to about $650 \mathrm{~km}$. were found for rays lying in the earth's shadow, a very remarkable fact. At $0^{\text {h }} 14^{\mathrm{m}}$ G.M.T. the whole intensity of the aurora. I had the impression that it had something to do with the white rays. At that time I had taken off the earphones from my ears (when I had them on, I heard nothing of this sound) and went some steps aside to hear it better; that the sound came from the telephone is quite excluded. The sound is difficult to describe, it was similar to the sound from burning grass and spray. On the mountain it was absolutely quiet, no sound coming from wind, waterfalls, telegraph lines or motors. Both my assistant and I heard it and are quite convinced that the sound was real. On the summit of the mountain where we had our station, only a few fir trees grow. Under us on all sides we had the forest."

The same sound was heard independently of Mr. Tjönn, down in the valley Tuddal, by Oystein Reisjaa, who in a letter has confirmed in all details the description given by Mr. Tjönn. When Mr. Tjönn heard the sound, he telephoned to me ; but I was so occupied by securing height determinations of the big corona that I did not pay sufficient attention to his call. On account of the great height of the aurora, it is clear that the sound could not come from the aurora itself, but from lower parts of the atmosphere; but where its origin was future observations may decide.

A very characteristic feature of the aurora of January 25-26 was the red colour, which ap. peared both as diffuse surfaces occupying sometimes vast areas of the sky, and as a red glow at the top of the aurora, well seen from stations so far south as heavens was filled with a gorgeous corona, and it was difficult to find parts of it characteristic enough to be measured. Only the base points of some rays towards the east against the dark sky behind could be measured, and a height of about $95 \mathrm{~km}$. was found. During this corona, which may be characterized as the maximum activity of the aurora in Norway that night, my assistant, Mr. Tjönn, at my station on Njuke Mountain in Tuddal, 733 metres above sea-level, reported that he heard sounds with the aurora. He says in a letter to me :

"During the imposing display of this big corona, where the whole heavens was like an ocean of flames, my assistant and I heard a curious sound which came from above, first from the south-west, then from the zenith and at last from the northeast. The sound lasted about ten minutes, rose to a maximum and fell down again, following the northern Africa and so far north as middle and northern Norway. This fact made it most probable that the red coloration reached enormous heights, and at $0^{\mathrm{h}} 35^{\mathrm{m}} 45^{\mathrm{s}}$ G.M.T. we also succeeded in getting simultaneous pictures of a red spot in the west-south-west from the three stations Askim, Oslo and Lillehammer on panchromatic plates, Agfa ISS. As the base-lines were almost normal to the direction to the spot, the determinations are fairly trustworthy. We found for the lowest part about $350 \mathrm{~km}$., and for the summit, almost $700 \mathrm{~km}$. above the earth. The spot was situated about $1,500 \mathrm{~km}$. away over the Atlantic Ocean north-west of Ireland, and was quite in the earth's shadow. I am sorry that the weather prevented us from measuring the sunlit parts of this aurora early in the evening. Records of auroral heights would probably have been the result. 
Among the spectra taken by my assistant, Herlofson, only a few need be mentioned. On the same Agfa ISS plate were taken two spectra when the spectrograph was pointed towards the green arc in the south mentioned in the first part of this report. They show the green line $5577 \mathrm{~A}$. as the strongest; then come with decreasing intensity the lines $6300 \mathrm{~A}$., $6550 \mathrm{~A}$. and $4278 \mathrm{~A}$. On the same plate were taken two spectra when the spectrograph was pointed towards red areas. They show $6300 \mathrm{~A}$., by far the strongest, next $5577 \mathrm{~A}$. and faint traces of $6550 \mathrm{~A}$. and $4278 \mathrm{~A}$.
On Agfa red ultra-rapid plate was taken with the same spectrograph a spectrum of the red colour in the southwest between $0^{\mathrm{h}} 10^{\mathrm{m}}$ and $0^{\text {h }} 30^{\mathrm{m}}$ G.M.T. Here 6300 is again by far the strongest line, then 6550 and 5577 about equally strong, and traces of 4278 . On the same plate were taken spectra of pulsating auroras and corruscations between $2^{\text {h }}$ and $4^{\text {h }}$ G.M.T., situated in the height interval from 90 to $120 \mathrm{~km}$. Here all four lines have about the same intensity.

Photometric measurements of these spectra will be made later.

\section{Medical Research in Great Britain}

$\mathrm{T}$ HE report of the Medical Research Council for 1936-37* gives, in summary form, an account of the researches carried out by members of its staff, either at the National Institute for Medical Research or in external institutions, as well as by the numerous investigators, working in different laboratories, who receive grants-in-aid from the Council. In this report, separate sections are devoted to the work carried out by members of the Council's staff in external institutions, instead of its being included in the sections also describing the investigations aided by grants, in order to give a truer picture of the organization of the Council's activities.

Lord Mildmay of Flete, treasurer of the Council, resigned his membership during the year; Mr. Goodenough was appointed to succeed him. Sir Thomas Lewis and Sir David Wilkie retired in rotation and were succeeded by Prof. Gask and Prof. Witts. The Council has made appointments to Dorothy Temple Cross research fellowships, to research fellowships in tropical medicine and also to Rockefeller medical fellowships. It will be recalled that last year it was announced that the Rockefeller Foundation had suspended the arrangement under which the Council awarded these fellowships, as it wished to concentrate its activities on certain selected fields of medical research: the Foundation has, however, now generously agreed to restore and augment the former arrangement. The Council has continued to maintain close touch, at relevant points in its work, with the Government departments concerned with questions of health and has also been closely concerned with international health work under the League of Nations, and especially with regard to questions of nutrition and of

- Committee of the Privy Council for Medical Research. Report of the Medical Research Council for the Year 1936-37. Pp. 165. (Londion : H. M. Stationery Office, 1938). 38. net. biological standards, upon the Commissions dealing with which it is directly represented.

The need for additional laboratories for work on chemotherapy and biological standards and for nutritional studies as well as to relieve the present overcrowding at the National Institute for Medical Research has led the Council to consider the possibilities of development at the present site at Hampstead and at the site of the farm laboratories at Mill Hill. Owing to the fact that the Hampstead site has been reported on as unsuitable for further development on the scale which is now in view, even without allowing any margin for future expansion, the Council has decided in principle to abandon this site and to concentrate the whole of the National Institute at Mill Hill. A final decision can be taken only in the light of a definite estimate of the cost, based on the detailed plans which are now being worked out. If the project can be undertaken at once, it should be possible to complete it within about two years, and to provide additional accommodation for some purposes at an earlier date.

The grant-in-aid provided by Parliament for the expenditure of the Medical Research Council was greater by $£ 30,000$ than the amount in the previous year, the difference representing special provision for the development of research work in chemotherapy. Chemotherapy is the treatment of infective diseases by the administration of chemical compounds synthesized in the laboratory, which have been found to have specific actions on the infective organisms associated with these diseases. The principal successes of this form of treatment have so far been in infections with spirochætes and protozoa rather than with bacteria, in venereal and tropical diseases rather than in the bacterial infections common in a temperate climate. Quite recently, however, success has attended the use 